\title{
Increase in dimethylsulfide (DMS) emissions due to eutrophication of coastal waters offsets their reduction due to ocean acidification
}

\author{
Nathalie Gypens ${ }^{1 *}$ and Alberto V. Borges ${ }^{2}$ \\ 1 Laboratoire d'Ecologie des Systèmes Aquatiques, Ecole Interfacultaire de Bioingénieurs, Université Libre de Bruxelles, Brussels, Belgium \\ 2 Unité d'Océanographie Chimique, Department of Astrophysics Geophysics and Oceanography, Institut de Physique (B5), Université de Liège, Liège, Belgium
}

Edited by:

Stelios Katsanevakis, Institute for Environment and Sustainability, Italy

\section{Reviewed by:}

Eric 'Pieter Achterberg, GEOMAR

Helmholtz Centre for Ocean

Research Kiel, Germany

Kevin John Flynn, Swansea

University, UK

Thomas George Bell, Plymouth

Marine Laboratory, UK

*Correspondence:

Nathalie Gypens, Laboratoire

d'Ecologie des Systèmes

Aquatiques, Ecole Interfacultaire de

Bioingénieurs, Université Libre de

Bruxelles, CP-221, Bd du Triomphe,

1050 Brussels, Belgium

e-mail:ngypens@ulb.ac.be
Available information from manipulative experiments suggested that the emission of dimethylsulfide (DMS) would decrease in response to the accumulation of anthropogenic $\mathrm{CO}_{2}$ in the ocean (ocean acidification). However, in coastal environments, the carbonate chemistry of surface waters was also strongly modified by eutrophication and related changes in biological activity (increased primary production and change in phytoplankton dominance) during the last 50 years. Here, we tested the hypothesis that DMS emissions in marine coastal environments also strongly responded to eutrophication in addition to ocean acidification at decadal timescales. We used the R-MIRO-BIOGAS model in the eutrophied Southern Bight of the North Sea characterized by intense blooms of Phaeocystis that are high producers of dimethylsulfoniopropionate (DMSP), the precursor of DMS. We showed that, for the period from 1951 to 2007, eutrophication actually led to an increase of DMS emissions much stronger than the response of DMS emissions to ocean acidification.

Keywords: dimethylsulfide (DMS), eutrophication, ocean acidification, coastal waters, Phaeocystis, modeling

\section{INTRODUCTION}

Dimethylsulfide (DMS) is the largest natural source of sulfur to the atmosphere, and may influence climate regulation by affecting atmospheric chemistry and the heat balance of the atmosphere (Charlson et al., 1987) though the significance of this feedback still remains uncertain (Carslaw et al., 2010; Quinn and Bates, 2011). Dimethylsulfoniopropionate (DMSP), the precursor of DMS, is mainly produced by a limited number of marine microalgae; Haptophytes and dinoflagellates being usually characterized by higher cellular DMSP concentrations than diatoms (Keller et al., 1989; Stefels et al., 2007). The modification of microalgae dominance and production in response to climate warming (e.g., Blanchard et al., 2012), eutrophication (e.g., Mackenzie et al., 2011), or ocean acidification (e.g., Doney et al., 2009) is then expected to change DMS emissions in the future with a potential positive or a negative feedback on climate change (Bopp et al., 2003; Gabric et al., 2004; Kloster et al., 2007; Vallina et al., 2007; Cameron-Smith et al., 2011; Six et al., 2013).

Ocean acidification of surface waters corresponds to the increase of $\left[\mathrm{CO}_{2}\right]$ and of $\left[\mathrm{H}^{+}\right]$, the decrease of $\mathrm{pH}$, of $\left[\mathrm{CO}_{3}^{2-}\right]$, and of the saturation state of calcium carbonate, all related to the input of anthropogenic $\mathrm{CO}_{2}$ from the atmosphere. These changes of the carbonate chemistry can alter the rates of primary production and calcification of numerous marine organisms and communities (Doney et al., 2009). Marine ecosystems also respond to other human pressures such as the increased delivery of nutrients from rivers to coastal waters mainly related to waste water discharge and use of fertilizers. This leads to eutrophication that corresponds to a general increase of primary production but also a change in the phytoplankton community and structure that impacts the whole food-web and ecosystem functioning (Cloern, 2001).

Several experiments based on the manipulation of the seawater carbonate chemistry in micro- or mesocosms have shown that ocean acidification is expected to change the DMS $(\mathrm{P})$ cycle (Vogt et al., 2008; Lee et al., 2009; Hopkins et al., 2010; Kim et al., 2010; Avgoustidi et al., 2012; Spielmeyer and Pohnert, 2012; Archer et al., 2013; Arnold et al., 2013). Six et al. (2013) used a simple relationship between DMS concentration and $\mathrm{pH}$ from a restricted set of experiments to predict the impact of ocean acidification on future climate through changes of the oceanic emission of DMS and its effect on atmospheric chemistry. However, in coastal environments, eutrophication is expected to counter to some extent the effect of ocean acidification on the dissolved carbonate chemistry of surface waters (Borges and Gypens, 2010). Further, DMS emissions would respond to the overall increase of primary production but also to the change of phytoplankton community structure related to eutrophication.

Here, we test the hypothesis that DMS emissions in coastal environments will also strongly respond to eutrophication in addition to ocean acidification at decadal timescales. We use as a case study the strongly eutrophied Southern Bight of the North Sea (SBNS) that is a hot spot of DMS emissions (Uher, 2006; Lana et al., 2011) because of the occurrence of intense blooms of Phaeocystis that are high DMSP producers. We use the R-MIROBIOGAS model that has been previously validated in the SBNS to which was added the parameterization of DMS change as a function of pH used in the global study of Six et al. (2013). 


\section{MATERIALS AND METHODS}

The R-MIRO-BIOGAS model results of the coupling between the RIVERSTRAHLER model, a biogeochemical model of the river system (Garnier et al., 2002), and the MIRO-BIOGAS model. The coupled model describes the biological transformation of $\mathrm{C}$, nitrogen $(\mathrm{N})$, phosphorus $(\mathrm{P})$, and silicate $(\mathrm{Si})$ along the rivercoastal continuum as a function of meteorological conditions and changing human activity on the watershed. $\mathrm{C}$ and nutrient river loads to the coastal zone are simulated by the RIVERSTRAHLER model from prescribed land use and human activities on the drainage basin (Billen et al., 2001, 2005; Passy et al., 2013). In the marine domain, MIRO-BIOGAS describes the dynamics of phytoplankton (diatoms, nanoflagellates and Phaeocystis), zooplankton and bacteria involved in the degradation of organic matter and the regeneration of inorganic nutrients in the water column and the sediment (Lancelot et al., 2005). The description of the carbonate system is based on the evolution of dissolved inorganic carbon (DIC) and total alkalinity (TA) and allows the calculation of partial pressure of $\mathrm{CO}_{2}\left(\mathrm{pCO}_{2}\right), \mathrm{pH}$ and air-sea $\mathrm{CO}_{2}$ fluxes (Gypens et al., 2004). The DMS(P) cycle describes the DMSP and DMS dynamics, including biological transformations by phytoplankton and bacteria, and physico-chemical processes (including photodegradation and DMS air-sea exchange) (Gypens et al., 2014).

To take account in the MIRO-BIOGAS model for the taxonspecific production of DMSP, the cellular production of DMSP is proportional to phytoplankton growth using a specific DMSP:C quota for each of the 3 phytoplankton groups described in the model (diatoms, nanoflagellates and Phaeocystis). The regulation of DMSP production by abiotic factors such as temperature, light, nutrients and salinity is not accounted. Indeed, at temperate latitudes, these effects are negligible (Stefels et al., 2007) and, as a first approximation, we consider that the cellular DMSP concentration of the different phytoplankton groups described in the model is fixed and specific (Gypens et al., 2014). The evolution of DMS concentration in the model results from its production by phytoplankton and bacterial enzymatic cleavage of DMSP in DMS and losses by bacterial consumption (assimilation and/or demethylation/methiolation), photochemical oxidation and emission to the atmosphere. The empirical relationship proposed by Six et al. (2013) modifies the DMS production (DMS prod $_{\text {) a }}$ a function of $\mathrm{pH}$ change according to:

$$
\mathrm{DMS}_{\text {prod_pH }}=\mathrm{F} * \mathrm{DMS}_{\text {prod_ref }}
$$

where $\mathrm{DMS}_{\text {prod_pH }}$ is the DMS production taking into account

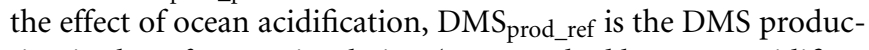
tion in the reference simulation (unperturbed by ocean acidification), and $\mathrm{F}$ is given by:

$$
\mathrm{F}=1+\gamma *\left(\mathrm{pH}_{\text {year }}-\mathrm{pH}_{1951}\right)
$$

where $\gamma$ corresponds to the value of the slope (0.58) of the linear regression of DMS concentration as function of $\mathrm{pH}$ in a selected number of mesocosm experiments that give a "medium" response according to Six et al. (2013), $\mathrm{pH}_{1951}$ corresponds to the $\mathrm{pH}$ mean daily value in 1951, and $\mathrm{pH}_{\text {year }}$ is the corresponding $\mathrm{pH}$ mean daily value computed for each year of the model simulation.

Note that $\mathrm{pH}$ effects on model variables other than DMS are not included in the model such as $\mathrm{pH}$ effects on primary production, for which no consensual parameterization is available. Results amongst manipulative studies are indeed highly variable reflecting either inconsistencies in experimental approach (Richier et al., 2014), or taxon-specific differences of the physiology response to ocean acidification (Flynn et al., 2012).

For this application, the model is implemented in a $0 \mathrm{D}$ frame of three successive boxes delineated on the basis of the hydrological regime and river inputs (Figure 1 in Lancelot et al., 2005) from the English Channel to the Belgian coastal zone (BCZ), and model results are analyzed for the BCZ influenced by the inflowing of Atlantic waters from the French coastal zone and the Scheldt river. Model simulations were performed from 1951 to 2007 after a 10 year spin-up run by constraining the model by daily wind speed, sea surface temperature (SST), monthly atmospheric $\mathrm{pCO}_{2}$, daily global solar radiation (climatology for 1989-1999), 10-days RIVERSTRAHLER simulations for C and nutrient river loads (Seine and Scheldt), and river DIC and TA inputs (Seine and Scheldt) computed as a function of freshwater discharge (Gypens et al., 2009).

Validation against field data and assessment of performance of the different components of the R-MIRO-BIOGAS model (RIVERSTRAHLER, R-MIRO, MIRO-CO2, MIRO-DMS) has been given and extensively discussed in other papers. Validation of the river loadings simulated by the RIVERSTRAHLER model for the Seine and Scheldt rivers during 1951-2007 was given by Billen et al. (2001, 2005) and Passy et al. (2013). Validation of the key biogeochemical variables simulated by R-MIRO such as nutrient concentration, phytoplankton composition and biomass (forced by the Seine and Scheldt river loadings simulated by RIVERSTRAHLER) in the BCZ was given by Lancelot et al. (2007) and Passy et al. (2013) for the Phaeocystis cells in particular. Validation of the seasonal and interannual variation of the seawater carbonate chemistry (DIC, TA, $\mathrm{pCO}_{2}$ ) simulated by MIRO-CO2 was given by Gypens et al. (2004, 2011). The validation of DMS(P) dynamics for the year 1989 simulated by MIRO-DMS was given by Gypens et al. (2014).

In addition to the reference simulation, two other simulations described in Table 1 were carried out to analyze model sensitivity to river inputs and atmospheric $\mathrm{CO}_{2}$ forcings. The effect of changes in SST and light was not tested as it was previously shown to have little impact on the long-term trend of simulated net primary production (NPP) and phytoplankton community composition (Lancelot et al., 2007).

\section{RESULTS AND DISCUSSION DMS EMISSIONS IN THE BCZ}

From 1951 to 2007, three periods can be distinguished in terms of river inputs of $\mathrm{N}$ and $\mathrm{P}$, quality of nutrient enrichment defined by winter-time dissolved inorganic nitrogen to phosphate (DIN:PO $\mathrm{P}_{4}$ ) ratio, NPP, and $\mathrm{pH}$ (Figures $\mathbf{1 A}, \mathbf{B}, \mathbf{C}$ ), as previously reported by Lancelot et al. (2007) and Borges and Gypens (2010). From 1951 to 1965, river nutrient inputs, NPP and $\mathrm{pH}$ remained stable. From 1966 to 1990, the river nutrient inputs increased and 
Table 1 | Description of the R-MIRO-BIOGAS simulations.

\begin{tabular}{|c|c|c|}
\hline Name & Setup & Application \\
\hline Reference-Simulation & All forcings vary & $\begin{array}{l}\text { Describes inter-annual variability and decadal changes } \\
\text { of DMS fluxes from } 1951 \text { to } 2007 \text { in the SBNS }\end{array}$ \\
\hline pH-Simulation & $\begin{array}{l}\text { Includes the parameterization of DMS concentration } \\
\text { change as a function of } \mathrm{pH} \text { given by Six et al. (2013) }\end{array}$ & $\begin{array}{l}\text { Allows to analyse the effect of pH change on DMS } \\
\text { emissions from } 1951 \text { to } 2007 \text { in the SBNS }\end{array}$ \\
\hline Ocean acidification only-Simulation & $\begin{array}{l}\text { All forcings are maintained at the } 1951 \text { values except } \\
\text { for atmospheric } \mathrm{pCO}_{2} \text { and includes the } \\
\text { parameterization of DMS concentration change as a } \\
\text { function of } \mathrm{pH} \text { given by Six et al. (2013) }\end{array}$ & $\begin{array}{l}\text { Allows to analyse the effect of increasing atmospheric } \\
\mathrm{CO}_{2} \text { on the inter-annual variability and decadal changes } \\
\text { of DMS emissions from } 1951 \text { to } 2007 \text { in the SBNS }\end{array}$ \\
\hline
\end{tabular}
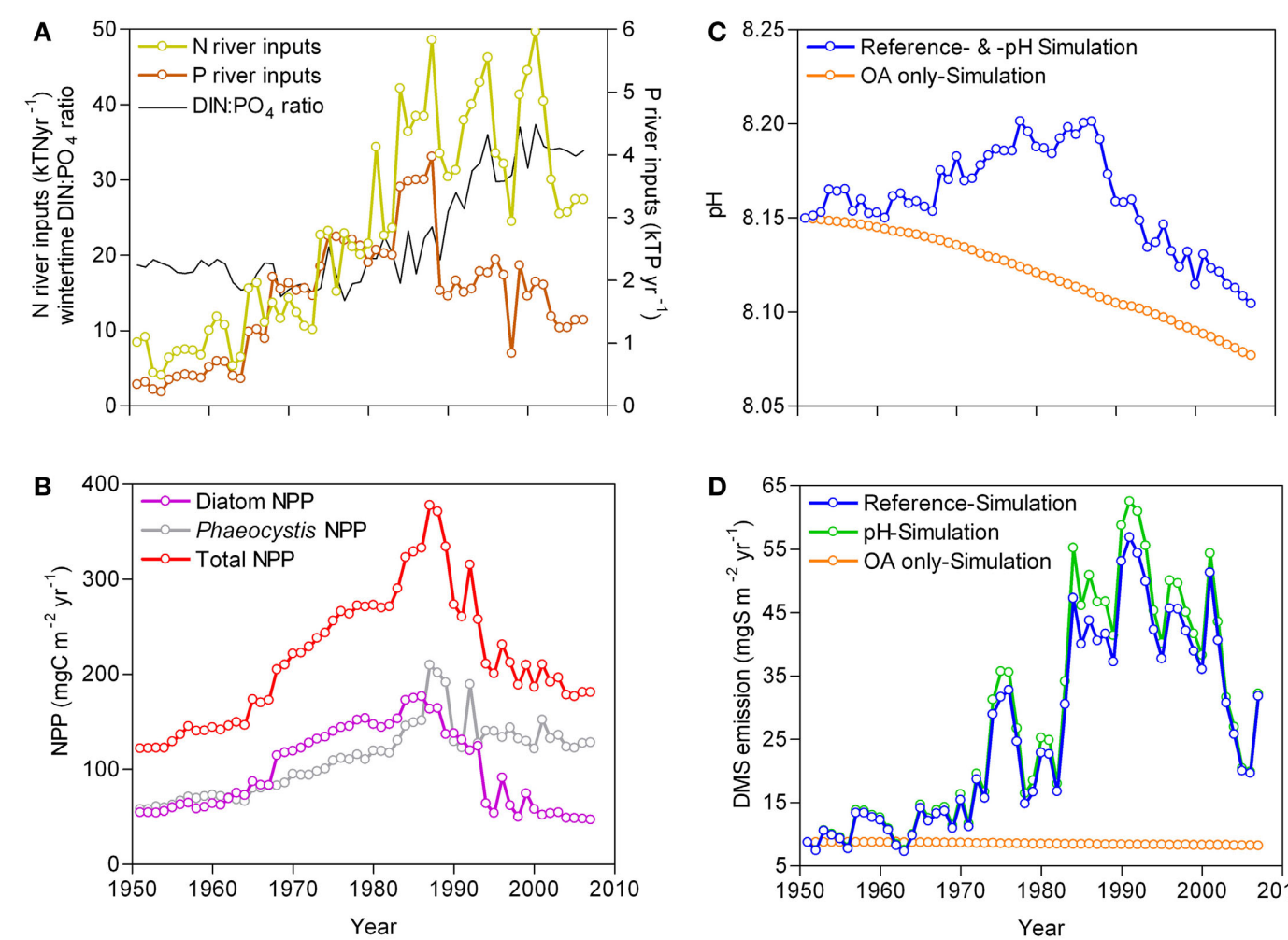

FIGURE 1 | Modeled evolution of (A) total $N$ and $P$ inputs from the Scheldt river and wintertime DIN: $\mathrm{PO}_{4}$ ratio, (B) net primary production (NPP) from diatoms and Phaeocystis, (C) pH, and (D) dimethylsulfide

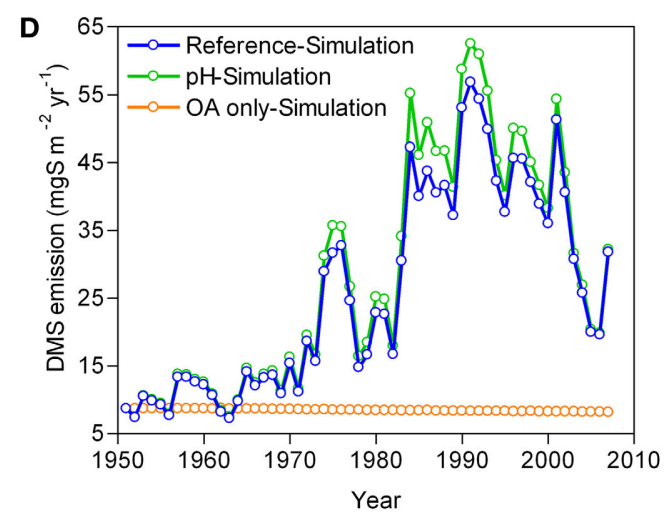

(DMS) emissions to the atmosphere in the Southern Bight of the North Sea from 1951 to 2007 given by the R-MIRO-BIOGAS model under the Reference-, pH- and Ocean acidification only-Simulation.

the winter-time $\mathrm{DIN}: \mathrm{PO}_{4}$ ratios remained close to phytoplankton requirements (Redfield ratio $=16: 1$; Redfield et al., 1963) leading to an increase of NPP and pH. From 1991 to 2007, the decrease of the total P river inputs (mainly due to removal of polyphosphates from washing powders) led to unbalanced winter-time DIN:PO $\mathrm{PO}_{4}$ ratios $(>16: 1)$ and a $\mathrm{P}$ limitation of primary production (Lancelot et al., 2007) accompanied by a decline of NPP and $\mathrm{pH}$. As previously described, from 1966 to 1990 , eutrophication by increasing NPP countered the decline of $\mathrm{pH}$ due to atmospheric $\mathrm{CO}_{2}$ increase (ocean acidification), while the decline of NPP between 1991 and 2007 led to a decline of $\mathrm{pH}$ faster than the one predicted from atmospheric $\mathrm{CO}_{2}$ increase alone (Borges and Gypens, 2010).
The emissions of DMS to the atmosphere (Figure 1D) responded strongly to the changes of NPP and in particular of Phaeocystis that accounts for about $80 \%$ of annual DMS emissions in the study area (Gypens et al., 2014). From 1951 to 1990,Phaeocystis accounted for about 50\% of total annual NPP, and on average 64\% from 1991 to 2007. From 1951 to 1965, the DMS emissions remained stable, but showed inter-annual variations that correspond to $\pm 22 \%$ of the overall annual mean. From 1966 to 1990 , the DMS emissions strongly increased at a rate of $14.4 \mathrm{mgS} \mathrm{m}^{-2}$ year $^{-1}$ decade $^{-1}\left(r^{2}=0.69, p<0.0001\right)$, while from 1991 to 2007 the DMS emissions strongly decreased at a rate of $-18.2 \mathrm{mgS} \mathrm{m}^{-2}$ year $^{-1}$ decade $^{-1}\left(r^{2}=0.69, p<0.0001\right)$. The highest DMS emission of $56.8 \mathrm{mgS} \mathrm{m}^{-2}$ year $^{-1}$ simulated 
in 1991 was 6.5 times higher than the one of 1951 (8.8 $\mathrm{mgS}$ $\mathrm{m}^{-2}$ year $\left.^{-1}\right)$. The annual DMS emission for the last year of the simulation period, 2007, (31.8 $\mathrm{mgS} \mathrm{m}^{-2}$ year $\left.{ }^{-1}\right)$ remained 3.6 times higher than the one of 1951. This shows that eutrophication strongly enhanced the DMS emissions to the atmosphere and also countered the effect of ocean acidification on DMS emissions. Indeed, a small $\left(-0.11 \mathrm{mgS} \mathrm{m}^{-2}\right.$ year $^{-1}$ decade $\left.^{-1}\right)$ but highly significant $\left(r^{2}=0.98, p<0.0001\right)$ decrease of DMS emissions was simulated between 1951 and 2007 when the system only reacted to the increase of atmospheric $\mathrm{CO}_{2}$ (Ocean acidification only-Simulation). Since $\mathrm{pH}$ actually increased from 1966 to 1990 (Figure 1B), the inclusion in the model of the parameterization of DMS production as function of $\mathrm{pH}$ given by Six et al. (2013) led to DMS emissions ( $\mathrm{pH}-$ Simulation) on average $\sim 9 \%$ higher compared to the Reference-Simulation (Figure 1D).

\section{DMS EMISSION IN THE GLOBAL COASTAL OCEAN}

The most recent estimate of global marine emission of DMS is $28.1 \mathrm{TgS}_{\text {year }}{ }^{-1}$ (Lana et al., 2011), although the respective part of emissions from continental shelves are not provided. We roughly evaluate DMS emissions from continental shelves assuming that DMS emissions are proportional to primary production (Bell et al., 2010; Miles et al., 2012; Kameyama et al., 2013). We used the average primary production value for coastal waters of $230 \mathrm{mgC} \mathrm{m}^{-2}$ year $^{-1}$, and for open ocean of $100 \mathrm{mgC} \mathrm{m}^{-2}$ year $^{-1}$ (Wollast, 1998). Using the global surface area of $27 \times 10^{6}$ $\mathrm{km}^{2}$ for continental shelves and of $335 \times 10^{6} \mathrm{~km}^{2}$ for the open ocean, globally integrated primary production in coastal waters is 6.2 PgC year $^{-1}$ vs. 33.5 PgC year ${ }^{-1}$ in the open ocean. This yields a global emission of DMS from continental shelves of $4.4 \mathrm{TgS}$ year $^{-1}$ vs. 23.7 $\mathrm{TgS}_{\text {year }}{ }^{-1}$ from the open ocean. We computed the primary production of coastal waters influenced by rivers based on the relative present day inputs of $\mathrm{N}$ from rivers of $43 \mathrm{TgN}$ year $^{-1}$ (Seitzinger et al., 2010) and the input of $\mathrm{N}$ by mixing and upwelling at continental margins of $380 \mathrm{TgN}_{\text {year }}{ }^{-1}$ (Wollast, 1998) that sustains primary production in the remaining continental shelves. This implies that coastal waters influenced by rivers have a DMS emission of $0.4 \mathrm{TgS}_{\text {year }}{ }^{-1}$ corresponding to $2 \%$ of total oceanic DMS emissions, and $10 \%$ of DMS emissions from continental shelves. Using a value of $18 \mathrm{TgN}$ year $^{-1}$ for pristine $\mathrm{N}$ river inputs (Meybeck, 1982), we can roughly evaluate that eutrophication has led to a $58 \%$ increase of DMS emissions from coastal waters influenced by rivers globally. This corresponds to the average increase globally, but regionally it is much higher, such as in the SBNS (510\% from 1951 to 1990). In the SBNS, the delivery of nutrients has been declining since the early 1990's, however, it is expected that globally $\mathrm{N}$ river inputs will continue to increase in future (Galloway et al., 2004). By 2050 , the total $\mathrm{N}$ inputs by rivers could range between $63 \mathrm{TgN}$ year $^{-1}$ (Galloway et al., 2004) and $77 \mathrm{TgN}_{\text {year }}{ }^{-1}$ (Mackenzie et al., 2011). Using the average value of $70 \mathrm{TgN}$ year $^{-1}$, DMS emissions from coastal waters influenced by rivers could increase by 2050 by $63 \%\left(0.7 \mathrm{TgS}\right.$ year $\left.^{-1}\right)$ that would correspond to about $3 \%$ of the present day total oceanic DMS emissions, for a region corresponding to only $\sim 0.5 \%$ of the total surface of the ocean.

\section{CONCLUSIONS}

We acknowledge that the change of marine DMS emissions in response to ocean acidification involves numerous and complex changes in DMS(P) sources and sinks. In particular, some studies point to an increase of DMSP production in parallel to either an increase of primary production, as both are usually correlated (e.g., Bell et al., 2010), or a change in phytoplankton dominance as a response to ocean acidification, although generally associated to a decrease of DMS emissions (Archer et al., 2013) or dissolved DMSP concentration (Lee et al., 2009). This indicates major modifications of DMS(P) cycling in particular by bacteria and zooplankton. However, the majority of manipulative experiments (micro- and mesocosms) converge to show a decrease of DMS emissions as a consequence of ocean acidification (Hopkins et al., 2010; Avgoustidi et al., 2012; Spielmeyer and Pohnert, 2012; Archer et al., 2013; Arnold et al., 2013), although some studies show the opposite response (Kim et al., 2010; Hopkins and Archer, 2014) for undetermined reasons. DMSP production by phytoplankton can also be modified by nutrient availability, not taken into account in this application. It has been suggested that $\mathrm{Fe}$ - and $\mathrm{N}$-limitation could increase DMSP cell quota and/or DMS emission (Sunda et al., 2002, 2007; Harada et al., 2009), but primary production in the studied zone is P-limited in general and Si-limited for diatoms (Lancelot et al., 2005, 2007). There are no or little changes in DMSP cell quota under Si- or P-limitation of primary production (Bucciarelli and Sunda, 2003).

Coastal environments are hotspots of DMS emissions and are subject to eutrophication. We showed that this major anthropogenic disturbance of marine ecosystems can lead to a stronger response of DMS emissions that actually counters the effect of ocean acidification in our particular case study in the SBNS. The response of DMS emissions to eutrophication at global scale cannot be currently modeled because the resolution of general ocean circulation models or earth system models is insufficient to represent coastal areas influenced by rivers. At present, these responses can only be investigated with regional models, hence, necessarily at local scales. We nevertheless attempted a first-order estimate of the global change of DMS emissions in response to eutrophication, and we evaluated an increase of about $63 \%$ of DMS emissions from coastal waters from present to 2050 as a result of increased NPP.

The parameterization of DMS concentration as function of pH used by Six et al. (2013) covers the range of relative changes of DMS concentrations observed so far in manipulative experiments. Hence, it is unlikely that a better representation of DMS(P) responses to ocean acidification would change the overall conclusion of the present work regarding to the relative effect of ocean acidification and eutrophication on DMS emissions in eutrophied coastal environments such as the SBNS.

\section{AUTHOR CONTRIBUTIONS}

Both authors contributed equally to this work Nathalie Gypens and Alberto V. Borges jointly conceived the study, designed the model simulations, and prepared the manuscript. Nathalie Gypens run the model and Alberto V. Borges conducted the global estimates of DMS emissions. 


\section{ACKNOWLEDGMENTS}

We are grateful for the comments from three anonymous reviewers. This contributes to project 2.4580 .11 (1882638) of the Fonds National de la Recherce Scientifique (FNRS) and to the EMOSEM (Ecosystem Models as Support to Eutrophication Management in the North Atlantic Ocean) EU FP7 ERA-NET Seas-era project funded by the Belgian Science Policy (BELSPO). Alberto V. Borges is a senior research associate at the FNRS, and co-first author.

\section{REFERENCES}

Archer, S. D., Kimmance, S. A., Stephens, J. A., Hopkins, F. E., Bellerby, R. G. J., Schulz, K. G., et al. (2013). Contrasting responses of DMS and DMSP to ocean acidification in Arctic waters. Biogeosciences 10, 1893-1908. doi: 10.5194/bg-101893-2013

Arnold, H. E., Kerrison, P., and Steinke, M. (2013). Interacting effects of ocean acidification and warming on growth and DMS-production in the haptophyte coccolithophore Emiliania huxleyi. Glob. Chang. Biol. 19, 1007-1016. doi: $10.1111 /$ gcb. 12105

Avgoustidi, V., Nightingale, P. D., Joint, I., Steinke, M., Turner, S. M., Hopkins, F. E., et al. (2012). Decreased marine dimethyl sulphide production under elevated $\mathrm{CO}_{2}$. Environ. Chem. 9, 399-404. doi: 10.1071/EN11125

Bell, T. G., Poulton, A. J., and Malin, G. (2010). Strong linkages between dimethylsulphoniopropionate (DMSP) and phytoplankton community physiology in a large subtropical and tropical Atlantic Ocean data set. Global Biogeochem. Cy. 24, GB3009. doi: 10.1029/2009GB003617

Billen, G., Garnier, J., Ficht, A., and Cun, C. (2001). Modeling the response of water quality in the Seine river estuary to human activity in its watershed over the last 50 years. Estuaries 24, 977-993. doi: 10.2307/1353011

Billen, G., Garnier, J., and Rousseau, V. (2005). Nutrient fluxes and water quality in the drainage network of the Scheldt basin over the last 50 years. Hydrobiologia 540, 47-67. doi: 10.1007/s10750-004-7103-1

Blanchard, J. L., Jennings, S., Holmes, R., Harle, J., Merino, G., Allen, J. I., et al. (2012). Potential consequences of climate change for primary production and fish production in large marine ecosystems. Philos. Trans. R. Soc. Lond. B Biol. Sci. 367, 2979-2989. doi: 10.1098/rstb.2012.0231

Bopp, L., Aumont, O., Belviso, S., and Monfray, P. (2003). Potential impact of climate change on marine dimethyl sulfide emissions. Tellus 55B, 11-22. doi: 10.1034/j.1600-0889.2003.042.x

Borges, A. V., and Gypens, N. (2010). Carbonate chemistry in the coastal zone responds more strongly to eutrophication than to ocean acidification. Limnol. Oceanogr. 55, 346-353. doi: 10.4319/lo.2010.55.1.0346

Bucciarelli, E., and Sunda, W. (2003). Influence of $\mathrm{CO}_{2}$, nitrate, phosphate, and silicate limitation on intracellular dimethylsulfoniopropionate in batch cultures of the coastal diatom Thalassiosira pseudonana. Limnol. Oceanogr. 48, 2256-2265. doi: 10.4319/lo.2003.48.6.2256

Cameron-Smith, P., Elliott, S., Maltrud, M., Erickson, D., and Wingenter, O. (2011). Changes in dimethyl sulfide oceanic distribution due to climate change. Geophys. Res. Lett. 38, L07704. doi: 10.1029/2011GL047069

Carslaw, K. S., Boucher, O., Spracklen, D. V., Mann, G. W., Rae, J. G. L., Woodward, S., et al. (2010). A review of natural aerosol interactions and feedbacks within the Earth system. Atmos. Chem. Phys. 10, 1701-1737 doi: 10.5194/acp-101701-2010

Charlson, R. J., Lovelock, J. E., Andreae, M. O., and Warren, S. G. (1987). Oceanic phytoplankton, atmospheric sulphur, cloud albedo and climate. Nature 326, 655-661. doi: 10.1038/326655a0

Cloern, J. E. (2001). Our evolving conceptual model of the coastal eutrophication problem. Mar. Ecol. Prog. Ser. 210, 223-253. doi: 10.3354/meps210223

Doney, S. C., Fabry, V. J., Feely, R. A., and Kleypas, J. A. (2009). Ocean acidification: the other $\mathrm{CO}_{2}$ problem. Annu. Rev. Mar. Sci. 1, 169-192. doi: 10.1146/annurev. marine.010908.163834

Flynn, K. J., Blackford, J. C., Baird, M. E., Raven, J. A., Clark, D. R., Beardall, J., et al. (2012). Changes in $\mathrm{pH}$ at the exterior surface of plankton with ocean acidification. Nat. Clim. Change 2, 510-513. doi: 10.1038/nclimate1696

Gabric, A. J., Simó, R., Cropp, R. A., Hirst, A. C., and Dachs, J. (2004). Modeling estimates of the global emission of dimethylsulfide under enhanced greenhouse conditions. Global Biogeochem. Cy. 18, GB2014. doi: 10.1029/2003 GB002183
Galloway, J. N., Dentener, F. J., Capone, D. G., Boyer, E. W., Howarth, R. W., Seitzinger, S. P., et al. (2004). Nitrogen cycles: past, present, and future. Biogeochemistry 70, 153-226. doi: 10.1007/s10533-004-0370-0

Garnier, J., Billen, G., Hannon, E., Fonbonne, S., Videnina, Y., and Soulie, M. (2002). Modeling transfer and retention of nutrients in the drainage network of the Danube River. Estuar. Coast. Shelf Sci. 54, 285-308. doi: 10.1006/ecss.2000.0648

Gypens, N., Borges, A. V., and Lancelot, C. (2009). Effect of eutrophication on airsea $\mathrm{CO}_{2}$ fluxes in the coastal Southern North Sea: a model study of the past 50 years. Glob. Change Biol. 15, 1040-1056. doi: 10.1111/j.1365-2486.2008.01773.x

Gypens, N., Borges, A. V., Speeckaert, G., and Lancelot, C. (2014). The dimethylsulfide cycle in the eutrophied Southern North Sea: a model study integrating phytoplankton and bacterial processes. PLoS ONE 9:e85862. doi: 10.1371/journal.pone.0085862

Gypens, N., Lacroix, G., Lancelot, C., and Borges, A. V. (2011). Seasonal and inter-annual variability of air-sea $\mathrm{CO} 2$ fluxes and seawater carbonate chemistry in the Southern North Sea. Prog. Oceanogr. 88, 59-77. doi: 10.1016/j.pocean.2010.11.004

Gypens, N., Lancelot, C., and Borges, A. V. (2004). Carbon dynamics and $\mathrm{CO}_{2}$ air-sea exchanges in the eutrophied coastal waters of the Southern Bight of the North Sea: a modelling study. Biogeosciences 1, 147-157. doi: 10.5194/bg-1147-2004

Harada, H., Vila-Costa, M., Cebrian, J., and Kiene, R. P. (2009). Effects of UV radiation and nitrate limitation on the production of biogenic sulfur compounds by marine phytoplankton. Aquat. Bot. 90, 37-42. doi: 10.1016/j.aquabot.2008.05.004

Hopkins, F. E., and Archer, S. D. (2014). Consistent increase in dimethyl sulphide (DMS) in response to high $\mathrm{CO}_{2}$ in five shipboard bioassays from contrasting NW European waters. Biogeosci. Discuss 11, 2267-2303. doi: 10.5194/bgd-112267-2014

Hopkins, F. E., Turner, S. M., Nightingale, P. D., Steinke, M., Bakker, D., and Liss, P. S. (2010). Ocean acidification and marine trace gas emissions. Proc. Natl. Acad. Sci. U.S.A. 107, 760-765. doi: 10.1073/pnas.0907163107

Kameyama, S., Tanimoto, H., Inomata, S., Yoshikawa-Inoue, H., Tsunogai, U., Tsuda, A., et al. (2013). Strong relationship between dimethyl sulfide and net community production in the western subarctic Pacific. Geophys. Res. Lett. 40, 3986-3990. doi: 10.1002/grl.50654

Keller, M. D., Bellows, W. K. K., and Guillard, R. R. (1989). "Dimethyl sulfide production in marine phytoplankton," in Biogenic Sulfur in the Environment, eds E. S. Saltzman and W. J. Cooper (Washington, DC: American Chemical Society), 167-182. doi: 10.1021/bk-1989-0393.ch011

Kim, J.-M., Lee, K., Yang, E. J., Shin, K., Noh, J. H., Park, K.-T., et al. (2010). Enhanced production of oceanic dimethylsulfide resulting from $\mathrm{CO}_{2}$-induced grazing activity in a high $\mathrm{CO}_{2}$ world. Environ. Sci. Technol. 44, 8140-8143. doi: $10.1021 /$ es102028k

Kloster, S., Six, K. D., Feichter, J., Maier-Reimer, E., Roeckner, E., Wetzel, P., et al. (2007). Response of dimethylsulfide (DMS) in the ocean and atmosphere to global warming. J. Geophys. Res. 112, G03005. doi: 10.1029/2006JG000224

Lana, A., Bell, T. G., Simó, R., Vallina, S. M., Ballabrera-Poy, J., Kettle, A. J., et al. (2011). An updated climatology of surface dimethlysulfide concentrations and emission fluxes in the global ocean. Global Biogeochem. Cy. 25, 1-17. doi: 10.1029/2010GB003850

Lancelot, C., Gypens, N., Billen, G., Garnier, J., and Roubeix, V. (2007). Testing an integrated river-ocean mathematical tool for linking marine eutrophication to land use: the Phaeocystis-dominated Belgian coastal zone (Southern North Sea) over the past 50 years. J. Mar. Syst. 64, 216-228. doi: 10.1016/j.jmarsys.2006.03.010

Lancelot, C., Spitz, Y., Gypens, N., Ruddick, K., Becquevort, S., Rousseau, V., et al. (2005). Modelling diatom and Phaeocystis blooms and nutrient cycles in the Southern Bight of the North Sea: the MIRO model. Mar. Ecol. Prog. Ser. 289, 63-78. doi: 10.3354/meps289063

Lee, P. A., Rudisill, J. R., Neeley, A. R., Maucher, J. M., Hutchins, D. A., Feng, Y., et al. (2009). Effects of increased pCO2 and temperature on the North Atlantic Spring Bloom. III. Dimethylsulfoniopropionate. Mar. Ecol. Prog. Ser. 388, 41-49. doi: 10.3354/meps08135

Mackenzie, F. T., De Carlo, E. H., and Lerman, A. (2011). “Coupled C, N, P, and O biogeochemical cycling at the Land-Ocean interface," in Treatise on Estuarine and Coastal Science, Vol. 5, eds E. Wolanski and D. S. McLusky (Waltham: Academic Press), 317-342. 
Meybeck, M. (1982). Carbon, nitrogen and phosphorus transport by world rivers. Am. J. Sci. 282, 401-450. doi: 10.2475/ajs.282.4.401

Miles, C. J., Bell, T. G., and Suntharalingam, P. (2012). Investigating the inter-relationships between water attenuated irradiance, primary production and DMS(P). Biogeochemistry 110, 201-213. doi: 10.1007/s10533-0119697-5

Passy, P., Gypens, N., Billen, G., Garnier, J., Thieu, V., Rousseau, V., et al. (2013). A model reconstruction of riverine nutrient fluxes and eutrophication in the Belgian Coastal Zone since 1984. J. Mar. Syst. 128, 106-122. doi: 10.1016/j.jmarsys.2013.05.005

Quinn, P. K., and Bates, T. S. (2011). The case against climate regulation via oceanic phytoplankton sulphur emissions. Nature 480, 51-56. doi: 10.1038/nature 10580

Redfield, A. C., Ketchum, B. A., and Richards, F. A. (1963). "The influence of organisms on the composition of sea-water," in The Sea, ed M. N. Hill (New York, NY: Wiley), 26-77.

Richier, S., Achterberg, E. P., Dumousseaud, C., Poulton, A. J., Suggett, D. J., Tyrrell, T., et al. (2014). Carbon cycling and phytoplankton responses within highlyreplicated shipboard carbonate chemistry manipulation experiments conducted around Northwest European Shelf Seas. Biogeosci. Discuss 11, 3489-3534. doi: 10.5194/bgd-11-3489-2014

Seitzinger, S. P., Mayorga, E., Bouwman, A. F., Kroeze, C., Beusen, A. H. W., Billen, G., et al. (2010). Global river nutrient export: a scenario analysis of past and future trends. Global Biogeochem. Cy. 24, GB0A08. doi: 10.1029/2009GB 003587

Six, K. D., Kloster, S., Ilyina, T., Archer, S. D., Zhang, K., and Maier-Reimer, E.(2013). Global warming amplified by reduced sulphur fluxes as a result of ocean acidification. Nat. Clim. Change 3, 975-978. doi: 10.1038/nclimate1981

Spielmeyer, A., and Pohnert, G. (2012). Influence of temperature and elevated carbon dioxide on the production of dimethylsulfoniopropionate and glycine betaine by marine phytoplankton. Mar. Environ. Res. 73, 62-69. doi: 10.1016/j.marenvres.2011.11.002

Stefels, J., Steinke, M., Turner, S. M., Malin, G., and Belviso, S. (2007). Environmental constraints on the production and removal of the climatically active gas dimethylsulphide (DMS) and implications for ecosystem modelling. Biogeochemistry 83, 245-275. doi: 10.1007/s10533-0079091-5
Sunda, W., Hardison, R., Kiene, R. P., Bucciarelli, E., and Harada, H. (2007). The effect of nitrogen limitation on cellular DMSP and DMS release in marine phytoplankton: climate feedback implications. Aquat. Sci. 69, 341-351. doi: 10.1007/s00027-007-0887-0

Sunda, W., Kieber, D. J., Kiene, R. P., and Huntsman, S. (2002). An antioxidant function for DMSP and DMS in marine algae. Nature 418, 317-320. doi: 10.1038 /nature00851

Uher, G. (2006) Distribution and air-sea exchange of reduced sulphur gases in European coastal waters. Estuar. Coast. Shelf Sci. 70, 338-360. doi: 10.1016/j.ecss.2006.05.050

Vallina, S. M., Simó, R., and Manizza, M. (2007). Weak response of oceanic dimethylsulfide to upper mixing shoaling induced by global warming. Proc. Natl. Acad. Sci. U.S.A. 104, 16004-16009. doi: 10.1073/pnas.0700843104

Vogt, M., Steinke, M., Turner, S., Paulino, A., Meyerhöfer, M., Riebesell, U., et al. (2008). Dynamics of dimethylsulphoniopropionate and dimethylsulphide under different $\mathrm{CO}_{2}$ concentrations during a mesocosm experiment. Biogeosciences 5, 407-419. doi: 10.5194/bg-5-407-2008

Wollast, R. (1998). "Evaluation and comparison of the global carbon cycle in the coastal zone and in the open ocean," in The Global Coastal Ocean, eds K. H. Brink and A. R. Robinson (New York, NY: John Wiley \& Sons), 213-252.

Conflict of Interest Statement: The authors declare that the research was conducted in the absence of any commercial or financial relationships that could be construed as a potential conflict of interest.

Received: 18 February 2014; accepted: 02 April 2014; published online: 22 April 2014. Citation: Gypens $N$ and Borges $A V$ (2014) Increase in dimethylsulfide (DMS) emissions due to eutrophication of coastal waters offsets their reduction due to ocean acidification. Front. Mar. Sci. 1:4. doi: 10.3389/fmars.2014.00004

This article was submitted to Marine Ecosystem Ecology, a section of the journal Frontiers in Marine Science.

Copyright (C) 2014 Gypens and Borges. This is an open-access article distributed under the terms of the Creative Commons Attribution License (CC BY). The use, distribution or reproduction in other forums is permitted, provided the original author(s) or licensor are credited and that the original publication in this journal is cited, in accordance with accepted academic practice. No use, distribution or reproduction is permitted which does not comply with these terms. 